\title{
United States Tax Reform: A Common Sense Approach
}

\author{
Confidence W. Amadi ${ }^{1} \&$ Felicia Y. Amadi ${ }^{2}$ \\ ${ }^{1}$ School of Business \& Economics, Elizabeth City State University, Elizabeth City, USA \\ ${ }^{2}$ Division of Business \& Finance, Elizabeth City State University, Elizabeth City, USA \\ Correspondence: Confidence W. Amadi, School of Business \& Economics, Elizabeth City State University, \\ Campus Box 781, 1704 Weeksville Road, Elizabeth City, NC 27909, USA. Tel: 1-252-335-3051. E-mail: \\ cwamadi@mail.ecsu.edu
}

$\begin{array}{lcc}\text { Received: February 25, } 2012 & \text { Accepted: May 12, } 2012 & \text { Published: June 1, } 2012 \\ \text { doi:10.5539/ijbm.v7n11p67 } & \text { URL: http://dx.doi.org/10.5539/ijbm.v7n11p67 }\end{array}$

\begin{abstract}
The fairness of the United States Tax system is at the center of the debate on economic growth and deficit reduction. The prevailing solutions seems centered on stimulating the economy by cutting taxes and cutting spending to minimize its impact on the federal budget deficit. The major area of disagreement lies in the fairness of the current tax system and the belief that the segment of the society most able to bear the cost of government are paying the least or not paying their fair share. The objective of this paper is to propose a tax code that is fair, a tax code that is simple enough that a taxpayer does not need a professional to help him or her to figure out their tax bill. This tax system is based on a combination of personal income tax, consumption tax and the elimination of the corporate income tax.
\end{abstract}

Keywords: consumption tax, corporate tax, tax code, value added tax

\section{Introduction}

The United States is suffering from the worst economic crisis since the Great Depression. Politicians and the like are clamoring for actions by the government to create jobs and get the economy moving again. Some believe in the traditional cut government spending and cut taxes to get the economy moving again. Others are advocating raising taxes and increasing or at the very least holding the line on spending. Cutting spending means a reduction in income to those who make the products and services that the government buys. The loss of income for these units will result in lost jobs. This goes against the goal of job creation. Cutting taxes means a loss in government revenues and the government will either have to cut spending and increase unemployment or borrow more money and increase the ballooning deficit.

Increasing taxes assumes that the goods and services provided by the government are essential enough to warrant a replacement of private consumption/investment with public (i.e. government) expenditure. There is little doubt that the United States government is spending too much, and when you are spending too much, you have three possible lines of action: cut spending, increase revenue or some combination of both.

This paper will to focus on the revenue side of this equation because, in a recession, the government is the consumer of last resort. This is the central tenant of fiscal policy objective of economic stabilization. One of the key problems in a recession is lack of demand for goods and services due to a decrease in disposable income. People without jobs (both the unemployed and underemployed) have reduced incomes; as a result, businesses loose the sales they could have made from their spending. The role of government is to ameliorate the effect of this loss in demand. Cutting government investments in infrastructure and spending through automatic stabilizers (unemployment, food stamps, etc.) is counter-productive. It is synonymous to adding fuel to fire. The rest of the paper is organized as follows: section I highlights some of the problems with the current tax system; section II discusses the proposed common sense tax system; section III suggests ways to streamline the tax code; and section IV provides some concluding remarks.

\section{Problems with the Current Tax System}

Seltzer (1997) highlights the complexity of the United States tax code in a case study of Hewlett-Packard. In the study, he finds that the firm employs 33 tax professionals working in what amounts to three full-time employees 
for five months in other to complete the firm's Federal tax forms. He also notes that even when it is a tax credit, the firm's definitions of "research and development" may not be the same as "qualified research eligible for R\&D tax credit under I.R.C. Section 41" (p. 493). Slemrod and Venkatesh (2002), based on a survey of 1,329 largest firms in the United States, find that these firms on the average spend about $\$ 1.565$ million annually on federal tax compliance. This translates to more than $\$ 2$ billion annually. This figure does not add to the productive capacity of the economy, but rather adds to the cost of goods and services without any corresponding benefit to the consumer. Despeignes (2005) notes that after the 1986 tax reform act, the number of tax brackets dropped from 15 to 2 . In 2005 , the number had gone up to 6 . For the same period, the pages in the US tax code went from 26,300 to 40,500 after the 1986 tax reform. As of 2005, Despeignes notes that the tax code was 60,044 pages long. The complexity of the tax code is exemplified by the increase in instructions as a result of the 2003 tax reform that reduced the capital gains tax from a top rate of 20 percent to 15 percent. This change resulted in an increase 15 additional lines in the tax form and 11 additional pages of instruction (Wiener, 2004). Durst (2006) writing on the effect of tax changes on the agricultural sector, concludes that "modification to these tax policies can affect not only the financial well-being of farm households but also the number and size of firms, their organizational structure, and their use of land, labor, and capital inputs" (page 8).

Mathieu, Price and Antwi (2010) in their study of the distribution of UK personal income tax compliance costs, find that on the average the time spent on personal income tax compliance for UK was 4.5 hours. On the other hand, Slemrod and Sorum (1984) find that for the United States, the time required to comply with the personal income tax was 21.7 hours. Although this number was before the 1986 tax reform, the Tax Reform Act of 1986 increased the complexity of the tax system (Slemrod \& Blumenthal, 1996). Harris (2008) observes that the U.S. loses $\$ 31$ billion a year to overstated credits and deductions, $\$ 53$ billion to under reported individual income, and $\$ 113$ billion to underreported small business income. This translates into $\$ 197$ billion gap between the taxes the internal revenue service could have collected to what it actually collected. Globalization is one of the many factors that have made the current United States tax system obsolete. Hines and Summers (2009) argue that greater mobility of economic activity and the resulting increase in the response of tax base to tax rates have increased the economic distortions created by taxation. Their study on the globalization effects of tax design show the following:

- The United States currently taxes personal and corporate income at higher rates compared to other countries

- Governments of small open economies rely more on expenditure (consumption) type taxes than do the United States

- United States is a small open economy relative to the global economy, yet it relies on personal and other income type taxes.

- Given the increasing demand for government services and the growing challenges and inefficiencies of other sources of tax revenue, governments will have to resort more and more to expenditure based taxation to meet their revenue needs.

\section{Common Sense Tax System}

In response to the appointment of a Tax Reform Panel, McLure (2005) lists some things that Tax Panel needs to consider in creating a new tax code. He points out that the role of taxes is to raise money for the government and not to spend it. That the tax system must be fair; that it must be uncomplicated so that taxpayers do not have to use the services of professional tax preparers in order to file their returns; and most important of all, it should be void of exemptions, deductions and credits. McLure's suggestions can be summarized in three basic principles that should be the foundation of the tax system.

\subsection{Principle 1: A progressive Tax System}

The progressivity system of taxation implicitly recognizes the diminishing marginal utility of assets. This principle holds that the more of a given asset you have, the less the value of an additional unit of that asset. Thus, a million dollars to a middle class family is transformational, while to a multi-millionaire, its effect will not alter his or her lifestyle. This is the law of diminishing marginal utility. The more of something you have, the less and less you value each additional unit of that item. This is why the flat tax proposal is regressive.

Another rationale for a progressive tax system is based on the concept that the more you benefit from a service or product the more that individual should be willing to pay for it. Conversely, the more the cost of not having a product or service, the more the individual will be willing to pay for the provision of that product or service. The wealthy benefit more (or stand to lose more from the lack thereof) of public goods such as infra-structure, legal 
system and the enforcement of private property rights, security, national defense, to name just a few. It makes sense that they should pay more for the provision of those public goods and services.

\subsection{Principle 2: All Income is Equal Regardless of the Source}

The current tax system penalizes labor and rewards capital. It is also regressive. Wealthy people disproportionately provide capital. The rest of the population supply labor. Thus, the segment of the population that can least afford to pay for government are expected to pay more to support the government than the wealthy. Moreover, labor can provide goods and services, but without labor, capital (money) cannot provide anything. In addition, it can be argued that capital is a product of labor and consequently without labor, there can be no capital. In from capital should not be given preferential treatment over income from labor. It should not matter if the income is a gift from a friend or inheritance or corporate dividends - income is income and should have equal treatment under the tax code.

\subsection{Principle 3: The Tax Code is not the Tool for Influencing Citizens' Behaviors}

This is not to say that the government may or may not choose to encourage certain aspects of society. Tax deductibility of charitable contributions is considered as a means for the government to support the missions of non-profit organizations as these missions are seen as providing public service to people. In an era of rising budget deficit and an unwillingness to raise revenue through higher taxes, it becomes prudent to ask if these charitable activities are more important in general than the government services that maybe dismantled in the name of deficit reduction. Cordes (2011) reports on the estimate of The Joint Committee on Taxations that the five-year revenue cost of charitable deductions is about $\$ 246.1$ billion. The problem with deduction for charitable donations is that it is very regressive, because it is proportional to the donor's marginal tax rate. Thus, the government is subsidizing the people for whom the marginal benefit of the donation far exceeds the marginal utility of the amount donated. Moreover, it begs the issue of the government subsidizing the private decisions of the donors.

Mortgage interest deductions is another of the tax expenditures the government incurs in order to encourage homeownership and realization of the "American Dream". Unfortunately, it not only distorts economic activity, but it is also expensive. The Joint Committee on Taxation estimates the cost of mortgage interest deduction in fiscal year 2010 was $\$ 103.7$ billion (Poterba \& Sinai, 2011). Poterba and Sinai also estimated the increase in federal and state tax revenues if the mortgage interest deduction was abolished at $\$ 72.4$ billion. Even though the cost of this deduction is high, the benefits do not seem to justify the expenditure. Poterba and Sinai go on to show that given the concentration of mortgages on younger homeowners and the fact that about two-thirds of homeowners itemize, while older homeowners have no mortgages, elimination of this deduction will result in a modest to no increase in taxes but with a significant increase in tax revenues.

Recognizing the beneficial effect to society based on familial structures, or the benevolence of charitable donations, or the ability to pass wealth to one's heirs or invest in homes, education, cars etc. the associated expenditures should be explicitly stated and executed independently without involvement of a tax system. Thus, the public and government can appropriately state and monitor the efficacy of (de)incentivizing efforts. With these core principles as foundation, below is a tax code/system that is both sensible and fair.

The proposed system has seven income brackets with an progressive marginal tax rate as shown below for illustrative purposes only:

\begin{tabular}{|c|c|}
\hline Income Bracket & Marginal Tax Rate \\
\hline$\$ 0$ to $\$ 20,000$ : & $0 \%$ \\
\hline$\$ 20,001$ to $\$ 50,000$ : & $10 \%$ \\
\hline$\$ 50,001$ to $\$ 100,000:$ & $15 \%$ \\
\hline$\$ 100,001$ to $\$ 250,000$ : & $20 \%$ \\
\hline$\$ 250,001$ to $\$ 500,000$ : & $25 \%$ \\
\hline$\$ 500,001$ to $\$ 1,000,000$ : & $30 \%$ \\
\hline Above $\$ 1,000,000$ : & $35 \%$ \\
\hline
\end{tabular}


In practice, the exact size of each bracket and the progressivity of the marginal tax rate would be set by the actual needs of the people. However, the progressivity of the marginal tax rate must be maintained so as to ensure that the law of diminishing marginal utility is applied to incomes.

\section{Replacement of the Corporate Income Tax with a Consumption Tax on Non-essential Items}

The United States dependence on income taxes for revenue makes it a rarity among high-income countries and the world at large. Most of the world relies on value-added or some form of consumption tax for revenue generation (Hines Jr., 2007). According to Hines Jr. "reliance on income taxation imposes higher tax burden on capital income than would be the case if the government instead made more extensive use of consumption taxes" ( page 50). This resistance to consumption tax, despite its advantages may in part be due to the real option value of the corporate income tax in and of itself (Amadi, 2011). Amadi demonstrates that because firms collect taxes as part of the price of each unit of product or service delivered, firms have the option to pay the taxes only if all expenses are covered. Thus the existence of corporate income tax lowers the risk of investments since capital budgeting cash flows and hence product price, are estimated on an after-tax basis.

Tax Havens are another drain on the United States tax revenues from both corporate tax and individual taxes. It is estimated that the federal government loses as much as $\$ 130$ billion per year from the shifting of both individual income and corporate profits into low-tax countries (Gravelle, 2009). The replacement of corporate income tax with a flat rate consumption tax will not impose more tax burden on consumers than they are already paying. Based on data from 2011 Economic Report of the President, Table 1 shows that on the average from 1990 to 2000, manufacturing firms paid 28.34 percent in Federal taxes. From 2002 to 2010 the average combined Federal and State taxes paid by the manufacturing firms was 24.07 percent. During the same period (1990 to 2010) based on the Federal taxes paid by manufacturing firms and the sales revenue, the ratio of taxes to sales (a.k.a. consumption tax rate equivalent) was 1.79 and 1.92 percent respectively, for periods 1990 to 2000 and 2002 to 2010. A comparison of the Federal Government business tax receipts and the business value added show that an average value added tax rate of 2.75 percent would have generated the same tax receipts from business as did the current corporate income tax system for the period 1990 through 2010. If consumption tax were based on total personal consumption, a consumption tax rate of 3.08 percent would have generated the same revenue for the government over the same period as did the corporate income tax system. Given that the corporate income tax paid by businesses over the past decade is 24.07 percent as contrasted with the top marginal tax rate of 35 percent, the distortion of the income tax system on corporate income becomes apparent. Businesses make investment decision based on the marginal tax rates, consumers on the average pay a tax on consumption (corporate goods and services) that are expected to cover the 35 percent marginal tax rate that the firm will pay. The difference between the marginal and average tax rate can be describes as the subsidy on business decisions and shareholders. This may explain the resistance towards the adoption of the consumption or value added tax system. Thus, the consumption tax is not a new tax. It simply replaces the current "hidden" taxes paid by consumers to corporations.

A flat tax on consumption would exclude essentials such as food and utilities such as water, gas and electricity. It would also exclude the purchase of automobiles and homes, which are investments not consumables.

The proposed consumption tax has several advantages that differentiate it from similar proposals:

- First, the exclusion of food, housing and transportation addresses the regressivity critique of a flat consumption tax, which is based on the fact that low to middle-income families spend a higher proportion of their earnings on food, shelter and transportation than those with higher incomes.

- A consumption tax has another collateral benefit - it increases the income pool by capturing some taxes due on income from underground economic activities.

- In addition, it is common knowledge that corporations go to great lengths to avoid paying taxes. Replacing corporate income tax with a consumption tax eliminates the distortionary effects of taxes on business investment decisions and sources of funding (e.g. interest from debt financing is tax deductible in contrast to equity financing) and the uncertainty and deadweight loss of legal tax evasion.

- Moreover, corporations no longer have to go overseas to find a tax haven. It is right here at home. Corporations will be eager to operate in the U.S., thereby investing in our economy and employing Americans.

- In theory, one might argue that a consumption tax would decrease buying power. However, in theory eliminating corporate taxes would lead to lower corporate costs and thus lower prices. Further, corporations will still be competing for the business of the American people who now arguably have 
less money to spend. If they do not lower their prices, people will be less able to purchase their products. Thus, the reduction in personal buying power would be offset by a lower overall cost of goods and services

Table 1. Comparisom of average corporate tax rate, consumption tax rate and value added tax (1990-2010) (All values are \$Billions except Tax Rates Except tax rates(\%))

\begin{tabular}{llllllllllll}
\hline YEAR & TC & GVAD & NS & MPBT & MPAT & TAX & FGBTR & ATR & CTRM & VATR & ACTR \\
\hline 1990 & 3835.5 & 4453.9 & 2810.7 & 158.1 & 110.1 & 48 & 118.1 & 30.36 & 1.71 & 2.65 & 3.08 \\
1991 & 3890.1 & 4558.6 & 2761.1 & 98.7 & 66.4 & 32.3 & 109.9 & 32.73 & 1.17 & 2.41 & 2.83 \\
1992 & 4236.9 & 4829.2 & 2890.2 & 31.4 & 22.1 & 9.3 & 118.8 & 29.62 & 0.32 & 2.46 & 2.80 \\
1993 & 4483.6 & 5084.1 & 3015.1 & 117.9 & 83.2 & 34.7 & 138.5 & 29.43 & 1.15 & 2.72 & 3.09 \\
1994 & 4750.8 & 5425.2 & 3255.8 & 243.5 & 174.9 & 68.6 & 156.7 & 28.17 & 2.11 & 2.89 & 3.30 \\
1995 & 4987.3 & 5677.8 & 3528.3 & 274.5 & 198.2 & 76.3 & 179.3 & 27.80 & 2.16 & 3.16 & 3.60 \\
1996 & 5273.6 & 6030.2 & 3757.6 & 306.6 & 224.9 & 81.7 & 190.6 & 26.65 & 2.17 & 3.16 & 3.61 \\
1997 & 5570.6 & 6442.8 & 3920 & 331.4 & 244.5 & 86.9 & 203 & 26.22 & 2.22 & 3.15 & 3.64 \\
1998 & 5918.5 & 6810.8 & 3949.4 & 314.7 & 234.4 & 80.3 & 204.2 & 25.52 & 2.03 & 3.00 & 3.45 \\
1999 & 6342.8 & 7249 & 4148.9 & 355.3 & 257.8 & 97.5 & 213 & 27.44 & 2.35 & 2.94 & 3.36
\end{tabular}

Adapted from 2011 Economic Report of the President: Tables : B-1; B-10; B-84; B-93

Series 1: Federal Tax Only, Series 2: Both State and Federal Tax

Average Tax Rate (1990-2010)

Averages for Series 1:1990-2000 Based on SIC

Averages for Series 2: 2002-2010 Based on NAICS

Where

TC Total Consumption

GVAD Gross Value Added by All Businesses

NS Manufacturing Net Sales

MPBT Manufacturing Profit Before Tax

MPAT Manufacturing Profit After Tax

TAX Manufacturing Tax

FGBTR Federal Government Business Tax Receipts

ATR Average Manufacturing Tax Rate

CTRM Average Manufacturing Tax per Dollar of Sales a.k.a. Consumption Tax Rate

VATR FGBTR/GVAD: Equivalent Value Added Tax Rate

ACTR Aggregate Consumption Tax Rate: FGBTR/TC

\section{Streamlining the Tax Code}

Poterba (2011) argue that one of the most efficient ways to increase income tax revenue is to broaden the tax base. As such he points out that the current tax deductions, credits and exclusions reduce tax revenues as well as distort economic activity by creating "complicated incentives that affect the ways taxpayers earn and spend their incomes"(page 451). He posits that eliminating some or all of the tax expenditures could both raise revenue and reduce that induced distortions of economic activity.

The proposed plan would allow the government to drastically reduce the complexity (and cost) of the tax system. Because government would incentivize public behavior using separate and more specifically accountable programs, exemptions and credits based on marital status, size of family/dependants, education etc. would be eliminated. All income is treated as equal regardless of the source; so for instance, income from estates and trusts 
distributed to the beneficiaries or capital gains are taxed just like any other income, further reducing the tax system's complexity. The result is a tax system that is simple and fair: a tax system that:

- eliminates the burden on corporations and allows them to grow and create jobs

- eliminates the preferential treatment of debt and the distortion of business investment decisions

- eliminates the "double taxation" of dividends that seem to penalize equity holders

- provides for more targeted and accountable government incentive programs

- addresses the burdens of taxes on lower to middle income citizens while still incentivizing risk taking and entrepreneurship by allowing wealth creation.

\section{Conclusion}

The tax code proposed in this paper could serve as a blue print for a solution to the United States tax code problem. I acknowledge that many constituents, for one reason or the other, may not like some element of this plan, but it makes sense in a number of fronts. In general, flat taxes are regressive because poorer people use a greater proportion of their income for consumption. However, poorer people also spend a greater proportion of their income on food, shelter, and transportation. Therefore, they would pay taxes on smaller proportion of their spent income relative to wealthier individuals thus correcting for the perceived regressivity. Under the current system, consumers are already paying a consumption tax in the form of corporate taxes. For corporations, taxes are a business expense that must be covered by the revenue generated from the sale of goods and fees for services rendered. Even though taxes are incorporated into the cost of goods and services, corporations go to great lengths to avoid paying taxes. Thus, by eliminating corporations from the equation and levying the tax directly on the people, government revenue might actually increase.

Although corporation will lose the real option benefit embedded in the corporate income tax system, they gain from savings on the need to maintain two sets of books, one for management and one for tax purposes. In addition, the savings from dead weight cost of tax preparation and compliance will offset the lost value from the real option. Finally, by eliminating corporate income taxes, United States can become an international tax haven. Corporations will be eager to operate in the U.S. so as to take advantage of the zero corporate income tax system. The influx of corporations and the return of United States firms that fled because of higher taxes will create an economic boom for the economy.

Finally, the proposed tax code has several advantages over the current system. It will reduce the tax code from several thousand pages to just a few pages. It will eliminate the corporate tax system and the distortion of economic decisions posed by the current system. The new tax system will reduce the tax forms to one or two pages, eliminating the need for a tax specialist to help figure out the tax bill. It will eliminate the unfairness created by the preferential treatment given to investment income (which favors the wealthy) over wage income which the middleclass relies on. It will capture all income regardless of the source through the consumption component of the tax code. It will put the United States in the same tax category as other major economies of the western world. Most of all, it will increase the tax receipts for the government without raising taxes as well as reducing the budget deficit through the reduction in the size of the internal revenue service.

\section{References}

Amadi, C. W. (2011). Corporate income tax as a real option on corporate earnings. International Business Research, 4(2), 3-10.

Cordes, J. J. (2011). Re-thinking the deduction for charitable contributions: Evaluating the effects of deficit-reduction proposals. National Tax Journal, 64(4), 1001-1024.

Despeignes, P. (2005). By the numbers. Fortune, 151(7), 26-26.

Durst, R. (2006). Changing federal tax policies affect farm households differently. Oregon Wheat, 8-11.

Economic report of the president (2011). To the Congress of the United States. Retrieved from http://www.nber.org/erp/ERP-2011.pdf

Gravelle, J. G. (2009). Tax havens: International tax avoidance and evasion. National Tax Journal, 62(4), 727-753.

Harris, M. (2008). How to pay zero taxes. Money, 37(4), 98-103.

Hines Jr., J. R. (2007). Taxing Consumption and other sins. Journal of Economic Perspective, 21(1), 49-68.

Hines Jr., J. R., \& Summers, L. H. (2009). How globalization affects tax design. NBER/Tax Policy \& the 
Economy (University of Chicago Press), 23, 123-157.

Mathieu, L., Price, C. W., \& Antwi, F. (2010). The distribution of UK personal income tax compliance costs. Applied Economics, 42, 351-368. $\quad$ Retrieved from http://www.informaworld.com/10.1080/00036840701604370

McLure Jr., C. E. (2005). A few things the tax reform panel needs to remember. National Tax Journal, 58(3), 367-369.

Poterba, J. M. (2011). Introduction: Economic analysis of tax expenditures. National Tax Journal, 64(2), 451-458.

Poterba, J. M., \& Sinai, T. (2011). Revenue costs and incentive effects of the mortgage interest deduction for owner-occupied housing. National Tax Journal, 64(2), 531-564.

Seltzer, D. (1997). Federal income tax compliance costs: A case study of Hewlett-Packard Company. National Tax Journal, 50(3), 487-493.

Slemrod, J. B., \& Blumenthal, M. (1996). The income tax compliance cost of big business. Public Finance Quarterly, 24(4), 411-438. Retrieved from http://pfr.sagepub.com/10.1177/109114219602400401

Slemrod, J. B., \& Sorum, N. (1984). The compliance cost of the U.S. individual income tax system. National Tax Journal, 37, 461-474.

Slemrod, J., \& Venkatesh, V. (2002). The income tax compliance cost of large and mid-sized business, a report to the IRS LMSB division, Ann Arbor: office of Tax policy Research, University of Michigan Business School.

Wiener, L. (2004). The tax puzzle. U.S. News \& World Report, 136(2), 52-54. 